\title{
The Effects of Different Levels of Rosehip Fruit Added in the Rations of Laying Hens Raised Under High Altitude and Cold Stress on Some Blood Parameters, Rectal Temperature, Fertility Rate and Chick Quality
}

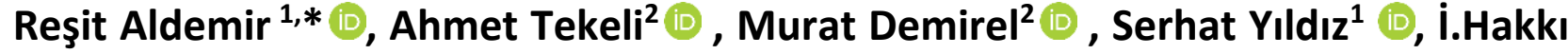 \\ Yörük ${ }^{3}$, , Saadet Belhan ${ }^{4}$ (D) , Volkan Koşal ${ }^{4}$ \\ ${ }^{1}$ Van Yüzüncü Yıl University, Gevaş Vocational School, Department of Veterinary Program, Van, Turkey \\ ${ }^{2}$ Van Yüzüncü Yıl University, Faculty of Agriculture, Department of Animal Science, Van, Turkey \\ ${ }^{3}$ Van Yüzüncü Yıl University, Faculty of Science, Department of Chemistry, Van, Turkey \\ ${ }^{4}$ Van Yüzüncü Yıl University, Faculty of Veterinary Medicine, Department of Reproduction and Artificial Insemination, \\ Van, Turkey \\ *Corresponding author
}

\section{Article History}

Received: 30 December 2020

Accepted: 09 March 2021

First Online: 15 April 2021

\section{Corresponding Author}

E-mail: resitaldemir@yyu.edu.tr

\section{Keywords}

Breeder hen

Rosehip fruit

Vitamine $\mathrm{C}$

Fertility rate

Chick quality

Blood parameters

\begin{abstract}
This study was carried out to determine the effects of different doses $(5 \mathrm{~g} / \mathrm{kg}$, $10 \mathrm{~g} / \mathrm{kg}, 15 \mathrm{~g} / \mathrm{kg}$ ) of rosehip fruit, which is a source of ascorbic acid (vitamine C), on fertility rate, chick quality and some blood parameters in the feed of breeder hens and roosters raised under high altitude and cold stress. It was applied during 12 -week trial. While the fertility rate was not significantly affected by the treatments, the plasma vitamine $C$ content of the laying hens was significantly affected by the treatments $(P<0.0001)$. While the lowest plasma vitamine $C$ content was determined as $34.54 \mathrm{\mu g} / \mathrm{ml}$ in the control group, it was determined as $53.23,133.40$ and $214.69 \mu \mathrm{g} / \mathrm{ml}$ in the groups receiving rosehip fruit, respectively. When the blood plasma values were examined, the difference among the groups was found to be significant only in terms of triglyceride values in laying hens and uric acid values in roosters $(P<0.05)$. Likewise, the difference among the groups in terms of hatching body weight values of chicks was found to be statistically significant $(P<0.05)$. As a result, it can be said that $5 \mathrm{~g} / \mathrm{kg}$ rosehip fruit can be added to the diets of breeder hens and roosters exposed to high altitude and cold stress.
\end{abstract}

\section{Introduction}

The significance of rosehip fruit (Rosa canina) in terms of health results from its bioflavonoid and carotenoid (lycopene, zeta-carotene, beta-carotene, xanthophyll, neoxanthin and lutein) content in addition to high vitamine and minerals it includes. Beta carotene is the main rosehip carotenoid and it has a significant place in the diet as pro-vitamine $A$ and anti-oxidant (Çınar et al., 2004). In addition to its nutritious value, rosehip also has protective properties against various ailments and partially treats various diseases (Kadakal and Nas, 2004). Rosehip fruits are used in the treatment of cold, flu and mild infections (Bown, 1996). It is known that rosehip, which is used as a drug raw material in many European countries, is also used in folk medicine against kidney and bladder stones, diarrhoea, gum bleeding and chest pain (Anonim 2008). Vitamine C, which has a great significance for human health and nutrition, is found in rosehip fruit in highest amount 
among fruit types in the world (Ağaoğlu et al., 1987). Rosehip fruits reach the highest vitamine $C$ rate in physiological maturity and this time generally corresponds to September-October (Anonim 2008). Although light coloured and fully ripe rosehip fruits contain more vitamine $\mathrm{C}$, very ripe and dark coloured fruits have less vitamine $C$ (Türkben, 2003). The most important feature of vitamine $C$ is the fact that it destroys the free radicals in our body. Free radicals may cause arteriosclerosis and cancer. Vitamine $\mathrm{C}$ is antioxidant due to its property of neutralizing these free radicals (Saraçoğlu, 2006; Untea et al., 2020). In addition to this feature, vitamine $\mathrm{C}$ is also used in poultry diets because of its positive effects on the immune system (Sasidhar, 2020) and as an anti-stress factor (Kutlu and Forbes, 1993; Shakeri et al., 2020). Değirmencioğlu and Ak (2003) found that the application of ascorbic acid (0, $50,100,150 \mathrm{mg} / \mathrm{kg}$ ) had no effect on nutrition performance in turkeys fed in the fall period. As a reason, they determined that animals were not exposed to low ambient temperatures. For this reason, it was concluded that new studies conducted in closer regions and at higher doses are needed to show the effects of ascorbic acid more clearly in preventing cold stress in animals.

With 70/524/EEC council directive on feed additives, European parliament and council regulations (EC) 1831/2003 defined CoE 403 numbered Rosa canina plant as a natural product and accepted it as a feed additive (Anonymous, 2013). Vitamine C, which is not essential for poultry and which can be synthesized by the animal, is generally not offered in the feed. However, adding vitamine $C$ to the feed is practically applied under stress conditions that reduce the synthesis of vitamine $C$ and increase the need for this vitamine (Kutlu, 2009). Therefore, it is hoped that the oxidative stress that will develop due to cold stress can be reduced with rosehip. The aim of this study was to find out the appropriate usage levels of natural rosehip fruit instead of commercial ascorbic acid in order to meet the vitamine $C$ requirement in breeding hens exposed to cold stress.

\section{Materials and Methods}

Animal material of the study consists of 120 Nick Brown hens at the age of 24 weeks and 15 Nick Brown roosters at the age of 24 weeks which were required for fertilized eggs. After obtaining permission for the study with the 25.10.2018 dated and 2018/10 numbered decision of Van YYU Animal Experiments Local Ethics Committee, the trial phase was carried out in Van YYU Research and Application Farm Directorate coop (at an altitude of $1726 \mathrm{~m}$ ). 5 groups were formed in the trial. While the group in which no additives were added constituted the control group, the groups in which 100 $\mathrm{mg} / \mathrm{kg}$ ascorbic acid (vitamine $\mathrm{C}$ ) and different doses of rosehip fruit $(5 \mathrm{~g} / \mathrm{kg}, 10 \mathrm{~g} / \mathrm{kg}, 15 \mathrm{~g} / \mathrm{kg})$ were added constituted the treatment groups (Table 1). Each group was divided into three subgroups with 8 hens and 1 rooster with similar average body weights and placed in cages prepared for breeding hens. The rosehip fruit used in the trials was collected in Gevaş and Edremit towns Nan in September and October when the rosehip fruit reached physiological maturity.

Each group was fed with $2850 \mathrm{ME}(\mathrm{kcal} / \mathrm{kg})$ basal ration including $16.75 \%$ HP prepared for breeding hens (Table 2). The hens and roosters placed randomly in cages were fed with ad-libitum feed and water. During the 12-week trial, 16 hours of light and 8 hours of dark lighting program was applied. In the trial unit, the temperature was set to $24^{\circ} \mathrm{C}$ for 12 hours and $14^{\circ} \mathrm{C}$ for 12 hours to create cold stress.

The blood required for checking blood parameters was taken from the under-wing vein. After removing the feathers on the lower surface of the wing, the vein was disinfected; 4-5 $\mathrm{ml}$ blood samples were taken into vacuum gel tubes by entering the vein with needle. Plasma was obtained by centrifuging blood samples at $3000 \mathrm{~d} / \mathrm{min}$ and room temperature for 15 minutes. The plasma was kept at $-20^{\circ} \mathrm{C}$ until analysis. Architect Abbott $\mathrm{Cl} 16200$ device and the commercial kits of this device in Van YYU Faculty of Medicine Biochemistry laboratory were used for blood analysis. Vitamine analysis in blood was made in Van YYU Central laboratory.

\section{Nutrient Analysis of Feed}

Dry matter, crude ash, crude protein, crude oil, crude fiber nutrient contents of the ration were determined by Wende analysis method (Akyıldız, 1984; AOAC, 1984). Starch, total P, Na, K, Cl and ME values are calculated according to the ration program.

Table 1. Groups in the experiment.

\begin{tabular}{lll}
\hline Group 1 & Control Group & No Additive \\
Group 2 & Ascorbic Acid (Vitamine C) Group & $100 \mathrm{mg} / \mathrm{kg}$ Vitamine C \\
Group 3 & Rosehip 1 & $5 \mathrm{~g} / \mathrm{kg}$ \\
Group 4 & Rosehip 2 & $10 \mathrm{~g} / \mathrm{kg}$ \\
Group 5 & Rosehip 3 & $15 \mathrm{~g} / \mathrm{kg}$ \\
\hline
\end{tabular}


Table 2. Composition and nutrient content if experimental diet.

\begin{tabular}{|c|c|c|c|}
\hline Raw materials & Rate(g/kg) & Analysed nutrients & (\%) \\
\hline Maize Corn & 55.63 & Dry Matter & 89.62 \\
\hline Feed Flour (46-52) & 15.000 & Crude Protein & 16.75 \\
\hline Soybean Meal (44) & 10.967 & Crude Celluse & 3.17 \\
\hline Fullfat Soybean & 6.346 & Crude Oil & 3.71 \\
\hline Marble Powder (GRN) & 6.326 & Crude Ash & 10.68 \\
\hline Sunflower Meal (34) & 3.032 & Starch & 44.96 \\
\hline DCP 18 & 1.636 & ME-Pou & 11.72 \\
\hline Salt & 0.244 & ME-Pou & 2.80 \\
\hline Sodium Bicarbonate & 0.190 & Tot-P & 0.61 \\
\hline DL-Methionine & 0.170 & $\mathrm{Na}$ & 0.16 \\
\hline Vitamine Premix ${ }^{1}$ & 0.200 & K & 0.62 \\
\hline Mineral Premix ${ }^{2}$ & 0.100 & $\mathrm{Cl}$ & 0.22 \\
\hline Choline chloride- $\% 60$ & 0.060 & & \\
\hline L-Threonine & 0.053 & & \\
\hline L-Lysine & 0.050 & & \\
\hline
\end{tabular}

1: In every 2 kg mixture; 12500000 IU Vitamine A, 3000000 IU Vitamine D3, 80000 mg Vitamine E, $5000 \mathrm{mg}$ Vitamine K3, $3000 \mathrm{mg}$ Vitamine B1, $12000 \mathrm{mg}$ Vitamine B2, $55000 \mathrm{mg}$ Niacin, $15000 \mathrm{mg}$ Ca-D-Pantothenate, $4000 \mathrm{mg}$ Vitamine B6, $40 \mathrm{mg}$ Vitamine B12, $2000 \mathrm{mg}$ Folic Acid, 250 mg D-Biotin

2: In every 1 kg mixture; 120000 mg Manganese, 60000 mg iron, 100000 mg zinc, 10000 mg copper, 500 mg Cobalt, 2000 mg iodine, 200 mg Selenium.

\section{Rosehip Vitamine C Analysis}

Vitamine $\mathrm{C}$ analysis was performed on $\mathrm{C}_{18}$ column (PhenomenexLuna $\mathrm{C}_{18}, 250 \times 4.60 \mathrm{~mm}, 5 \mu$ ) in HPLC (high performance liquid chromatography). Column oven temperature was set to $25^{\circ} \mathrm{C}$. Ultra-pure water, $\mathrm{pH}$ level adjusted to 2.2 with $\mathrm{H}_{2} \mathrm{SO}_{4}$, was used as mobile phase in the system at a flow rate of $1 \mathrm{ml} /$ minute. The readings were performed on a DAD detector at $254 \mathrm{~nm}$ wave length.

L-ascorbic acid (Sigma A5960) prepared in different concentrations $(50,100,500,1000,2000$ ppm) was used to define vitamine $C$ peak and to determine its amount (Demir and Özcan, 2001).

\section{Plasma Vitamine Analyses}

Vitamine $A, E$ and $C$ levels in plasma samples were determined with HPLC device. Vitamine $A$ and $E$ analyses were made according to (Zaspel and Csallany, 1983; Miller and Yang, 1985) and vitamine C analyses were made according to (Kartepe, 2004).

\section{Vitamine $\mathrm{A}$ and E Plasma Extractions}

$200 \mu$ l plasma was taken into plastic tubes for vitamine $A$ and $E$ analyses. They were added $200 \mu \mathrm{l}$ ethanol and mixed with vortex for a minute. These were added $800 \mu \mathrm{l}$-hexane and vortexed again for a minute and centrifuged for 10 minutes at 2000 RPM. $600 \mu$ l was taken from the resulting hexane phase and dried under nitrogen gas. The residue was dissolved in $500 \mu \mathrm{l}$ methanol and injected on the HPLC column (Zaspel and Csallany, 1983; Miller and Yang, 1985).

The setups were made ready for analyses by using vitamine $A$ and $E$ standard. $20 \mu \mathrm{l}$ was then taken from the prepared extracts and injected into the liquid chromatography column. The diagnoses of vitamine $A$ and $\mathrm{E}$ were made using DAD (diode-array detector) detector at 325 and $290 \mathrm{~nm}$ wavelengths. Methanolwater (98:2) was used as the mobile phase at a flow rate of $1.5 \mathrm{ml} / \mathrm{min}$. C18 column $(4.6 \mathrm{~mm} \times 25 \mathrm{~cm}$ ) was used to separate the vitamines (Kadakal and Nas, 2004; Donsbough et al., 2010). The calculations were made according to peak area and concentrations of vitamine $A$ and E standards.

\section{Plasma Vitamine C Determination}

The levels of vitamine $C$ in plasmas were determined with HPLC-UV method as stated by Karatepe (2004). For plasma analysis, $250 \mu \mathrm{l}$ of $0.1 \mathrm{M}$ $\mathrm{HClO} 4$ solution was added on $200 \mu \mathrm{l}$ plasma and vortexed for a few seconds, then $550 \mu$ l distilled water was added and after vortexing 10 minutes of centrifugation was made at 4500 RPM. Following these procedures, the supernatant was carefully removed, placed in a vial and vitamine $C$ levels were determined 
with HPLC. C18 column ( $25 \mathrm{~cm} \times 4.6 \mathrm{~mm})$ was used in the HPLC device with a mobile phase of $30 \mu \mathrm{M} \mathrm{KH}_{2} \mathrm{PO}_{4}$ methanol $(82.5: 17.5)$ at a flow rate of $1.2 \mathrm{ml} / \mathrm{min}$. The readings were made at $250 \mathrm{~nm}$ wave length with UV detector. The calculations were made according to peak area and concentrations of vitamine $\mathrm{C}$ standards.

\section{Fertility Rate and Chick Quality Values}

Fertility rate was found by using the formula below (Türker et al., 2018).

Fertility rate $(\%)=$ (The number of fertilized eggs)/(The number of eggs put in machine) $X 100$

Hatching weight and body length were evaluated as chick quality value. Chick body length was measured with the tip of the chick beak and the tip of the long finger stretched on the ruler (Şeremet, 2012).

\section{Statistical Analysis}

In the study conducted according to randomized plot design, SAS (2010) package program was used to analyse the data obtained. DUNCAN multiple comparison test was used to find out the difference between groups (Bek and Efe, 1998).

\section{Results and Discussion}

Vitamine $C$ content of the rosehip fruit used in the study was determined as $2862.66 \mathrm{mg}$ in $100 \mathrm{~g}$ (Table 3).

Table 3. Vitamine C content of rosehip fruit.

\begin{tabular}{lc}
\hline Rosehip fruit $\quad$ Vitamine C (mg/100g) \\
\cline { 2 - 2 } \\
\hline
\end{tabular}

This content was found to be higher than the vitamine $\mathrm{C}$ content in the rosehip fruit collected in Konya as $2365 \mathrm{mg} / 100 \mathrm{~g}$ and in Kastamonu as $2712 \mathrm{mg} / 100 \mathrm{~g}$ (Demir and Özcan, 2001). This difference can be attributed to the high altitude of the area and the higher number of sunny days in the area rosehip fruit used in the present study was grown.

When the effect of adding rosehip fruit to the ration on rectal temperature values in roosters was examined (Table 4), the difference between the means of groups was not found to be statistically significant $(P>0.05)$. While the mean rectal temperature of roosters before stress was found as $41.4^{\circ} \mathrm{C}$, rectal temperature was found to decrease to $40.9^{\circ} \mathrm{C}$ with cold stress. It is natural for rectal temperature values of the animals to decrease with cold stress. This difference was not found to be statistically significant in the present study. Similarly, Ahmed et al. (2008) reported that the vitamine $C$ supplement added in the drinking water of laying hens raised under sub-tropical conditions did not affect the rectal temperature values significantly. However, Tekeli (2014) added 0 (Control), 10, 20, 30 $\mathrm{g} / \mathrm{kg}$ rosehip fruit to the ration in a study conducted with broilers and found the pre-stress and post-stress rectal temperature values as $40.8-39.8^{\circ} \mathrm{C}, 40.9-39.7^{\circ} \mathrm{C}, 41.1$ $39.9^{\circ} \mathrm{C}, 40.8-39.5^{\circ} \mathrm{C}$ and reported that this difference was statistically significant $(P<0.05)$. This result is not in parallel with the result obtained from the present study. This difference in rectal temperature values may have resulted from the animal's races, ages and differences in the ration they consumed.

In Table 5, when the effect of adding rosehip fruit in the ration on laying hen's fertility rate and the quality values of the chicks was examined, the difference between means of the groups in fertility rate and body length values was not found to be statistically significant $(P>0.05)$. When the egg fertility rates were examined, the highest value was found in the group that received $5 \mathrm{~g} / \mathrm{kg}$ rosehip fruit with $97.53 \%$, while the lowest value was found in the group that received $15 \mathrm{~g} / \mathrm{kg}$ rosehip fruit with $92 \%$. In a study conducted by Shit et al. (2012), it was reported that adding vitamine $\mathrm{C}$ to the ration of quail exposed to cold stress $\left(10.47^{\circ} \mathrm{C}\right)$ had a positive effect on fertility. In the same study, while fertility rate was $72.5 \%$ in the control group, it was found as $94.57 \%$ in the group which was added 500 ppm L-ascorbic acid.

Table 4. The effect of addition of vitamine $C$ and Rosehip fruit doses to the ration on rectal temperature values in males.

Experiment Groups

\begin{tabular}{lccccccc}
\cline { 2 - 5 } & $\begin{array}{l}\text { 1. Group } \\
\text { (Control) }\end{array}$ & $\begin{array}{c}\text { 2. Group } \\
\text { (Commercial } \\
\text { Ascorbic Acid) }\end{array}$ & $\begin{array}{c}\text { 3. Group } \\
(5 \mathrm{~g} / \mathrm{kg}) \\
\text { Rosehip }\end{array}$ & $\begin{array}{c}4 . \text { Group } \\
(10 \mathrm{~g} / \mathrm{kg}) \\
\text { Rosehip }\end{array}$ & $\begin{array}{c}5 . \text { Group } \\
(15 \mathrm{~g} / \mathrm{kg}) \\
\text { Rosehip }\end{array}$ & SEM & P value \\
$\begin{array}{l}\text { Pre-stress } \\
\text { temperature }\left({ }^{\circ} \mathrm{C}\right)\end{array}$ & 41.27 & 41.50 & 41.40 & 41.60 & 41.36 & 0.0560 & 0.2576 \\
$\begin{array}{l}\text { Post-stress } \\
\text { temperature }\left({ }^{\circ} \mathrm{C}\right)\end{array}$ & 41.00 & 41.03 & 40.76 & 41.00 & 40.76 & 0.0617 & 0.1819 \\
\hline
\end{tabular}


Table 5. The effect of addition of vitamine $C$ and Rosehip fruit doses to the ration on fertility rate and quality values of chicks hatching.

\begin{tabular}{|c|c|c|c|c|c|c|c|}
\hline \multirow[b]{2}{*}{ Parameters } & \multicolumn{7}{|c|}{ Experiment Groups } \\
\hline & $\begin{array}{l}\text { Group } 1 \\
\text { (Control) }\end{array}$ & $\begin{array}{l}\text { Group } 2 \\
\text { (Ascorbic } \\
\text { Acid) }\end{array}$ & $\begin{array}{l}\text { Group } 3 \\
\text { (5g/kg) } \\
\text { Rosehip }\end{array}$ & $\begin{array}{l}\text { Group } 4 \\
(10 \mathrm{~g} / \mathrm{kg}) \\
\text { Rosehip }\end{array}$ & $\begin{array}{l}\text { Group } 5 \\
(15 \mathrm{~g} / \mathrm{kg}) \\
\text { Rosehip }\end{array}$ & SEM & $P$ value \\
\hline Fertility rate (\%) & 94.87 & 95.12 & 97.53 & 95.06 & 92.00 & 2.1732 & 0.8495 \\
\hline $\begin{array}{l}\text { Hatching body } \\
\text { weight }(\mathrm{g})\end{array}$ & $41.51 \mathrm{abc}$ & $41.84 a b$ & $41.98 a$ & $40.23 c$ & $40.45 b c$ & 0.2086 & 0.0092 \\
\hline Body length $(\mathrm{cm})$ & 17.46 & 17.20 & 16.98 & 16.98 & 17.11 & 0.0523 & 0.0676 \\
\hline
\end{tabular}

SEM: Standard error of difference between means.

*: The difference between the group average shown by different letters on the same line is statistically significant $(\mathrm{P}<0.05)$.

In a similar study, it was reported that adding Lascorbic acid had a positive effect on fertility in poultry under oxidative stress (Ahmadu et al., 2016). The results of these studies are not similar to the results of the present study. This difference can be attributed to the difference in the form and dose of the additives used. The difference between the group means in terms of body weight at hatching was found to be statistically significant $(P<0.05)$.

The highest hatching body weight was found in the group that received $5 \mathrm{~g} / \mathrm{kg}$ rosehip fruit, similar to the fertility rate. In a study on hatching chick weight, it was reported that adding ascorbic acid obtained from 0,200 , 500, 1000 and $1500 \mathrm{mg} / \mathrm{kg}$ DM orange peels to the ration did not affect chick hatching weight significantly (Adesola et al., 2013). These results are inconsistent with the results obtained in the present study in terms of hatching body weight. This difference can be attributed to the environmental conditions of the trial and the differences in forms and doses of the additives used. In addition, factors such as genetic factors, herd age, hatching egg quality, egg collection time, egg storing conditions, incubation temperature and egg weight are also reported to be effective on chick quality features such as chick weight and length (Kamanlı and Durmuş, 2014).

When Table 6 is examined, it was found that the rosehip fruit added in the rations of laying hens which were exposed to cold stress did not affect the amount of retinol and alpha tocopherol in the blood plasma of hens statistically significantly $(P>0.05)$. However, the difference between the groups in terms of the amount of vitamine $C$ in blood plasma was found to be statistically significant $(P<0.0001)$.

Table 6. The effect of addition of vitamine $\mathrm{C}$ and Rosehip fruit doses to the ration on laying hens blood plasma vitamine values.

\begin{tabular}{|c|c|c|c|c|c|c|c|}
\hline \multirow[b]{2}{*}{ Parameters } & \multicolumn{5}{|c|}{ Experiment Groups } & & \\
\hline & $\begin{array}{l}\text { Group } 1 \\
\text { (Control) }\end{array}$ & $\begin{array}{l}\text { Group } 2 \\
\text { (Commercial } \\
\text { ascorbic acid) }\end{array}$ & $\begin{array}{l}\text { Group } 3 \\
\text { (5g/kg) } \\
\text { Rosehip }\end{array}$ & $\begin{array}{l}\text { Group } 4 \\
(10 \mathrm{~g} / \mathrm{kg}) \\
\text { Rosehip }\end{array}$ & $\begin{array}{l}\text { Group } 5 \\
(15 g / k g) \\
\text { Rosehip }\end{array}$ & SEM & $P$ value \\
\hline Retinol, $(\mu \mathrm{g} / \mathrm{ml})$ & 0.28 & 0.22 & 0.28 & 0.26 & 0.21 & 0.0112 & 0.1000 \\
\hline $\begin{array}{l}\text { Alpha tocopherol, } \\
(\mu \mathrm{g} / \mathrm{ml})\end{array}$ & 4.22 & 2.93 & 4.15 & 3.87 & 2.84 & 0.0138 & 0.138 \\
\hline Vitamine $C,(\mu \mathrm{g} / \mathrm{ml})$ & $34.54 c$ & $47.06 c$ & $53.23 c$ & $133.40 \mathrm{~b}$ & 214.69a & 6.4326 & $<0.0001$ \\
\hline
\end{tabular}

SEM: Standard error of difference between means.

*: The difference between the group average shown by different letters on the same line is statistically significant $(P<0.05)$. 
While the plasma vitamine C value was $34.54 \mu \mathrm{g} / \mathrm{ml}$ in the control group, the highest vitamine $C$ value was found in the group that received $15 \mathrm{~g} / \mathrm{kg}$ rosehip fruit with $214.69 \mu \mathrm{g} / \mathrm{ml}$. Similarly, Ahmed et al. (2008) reported that levels of vitamine $\mathrm{C}$ added in increasing levels in the drinking water of laying hens placed under sub-tropical conditions increased plasma vitamine $C$ levels significantly. Exogenous vitamines such as alpha tocopherol and vitamine $C$ protect the cells against lipid peroxidation.

Lipid peroxidation leads to the deterioration of physiological functions including immunity, growth and reproduction (Altıner et al., 2017). The linear increase in the vitamine $\mathrm{C}$ level in blood with increasing doses of rosehip fruit can be explained with adding the rosehip fruit in the ration in increasing doses.

As can be seen in Table 7, the rosehip fruit added in the rations of laying hens exposed to cold stress significantly affected the level of triglyceride in hens' blood plasma $(P<0.05)$. In the present study, while the level of triglyceride in the control group was 1214.00 $\mathrm{mg} / \mathrm{dL}$, it was found to decrease significantly in the group that received $5 \mathrm{~g} / \mathrm{kg}$ rosehip fruit and it was found as $409.60 \mathrm{mg} / \mathrm{dL}$. High level of triglyceride in the blood has been associated with the emergence of a large number of important diseases, mainly cardiovascular diseases (Tada et al., 2018). Therefore, $5 \mathrm{~g} / \mathrm{kg}$ rosehip supplement is evaluated as important in terms of health. Similarly, Mutlu et al. (2015) reported that gypsum extract decreased blood triglyceride level significantly in quails exposed to cold stress. Behboudi et al. (2016) reported that the use of lemon juice as a source of vitamine $C$ significantly lowered the level of triglyceride in broilers bred under heat stress. Unlike the present study, in their study they added Berberis vulgaris fruit used as a source of vitamine $C$ in laying hens' rations, Kermanshahi and Riasi (2006) reported that the value of blood triglyceride was not significantly affected. Tekeli (2014) reported that using different doses of rosehip fruit in broilers exposed to cold stress did not affect blood plasma triglyceride levels significantly. Arpat (2016) reported that rosehip fruit used in laying hens did not have a significant effect on blood triglyceride value. The inconsistency between these studies may have resulted from the differences in the source of vitamine $C$, type of animal, sex of the animal, purpose of breeding, conditions of breeding and the content of the basic ration used. As can be seen in Table 7, the rosehip fruit added in the rations of laying hens exposed to cold stress caused numerical differences in the amount of cholesterol, glucose, uric acid, sodium, ALT, AST and GGT in hens' blood plasma, while this difference was not found to be statistically significant $(P>0.05)$. Similarly, Tekeli (2014) reported that rosehip fruit added in the ration of broilers did not affect the glucose and uric acid levels. Arpat (2016) reported that adding different rates of rosehip $(0,0.5,1,2,4$ and $8 \%)$ in the rations of laying hens did not affect blood plasma, cholesterol, AST and ALT values.

Unlike the present study, in a study conducted on broilers, it was reported that adding rosehip fruit to different doses of ration $(0,10,20,30 \mathrm{~g} / \mathrm{kg})$ under cold stress affected the level of blood plasma cholesterol level significantly (Tekeli, 2014). In their study they added Berberis vulgaris fruit to the rations of laying hens as $0,0.5,1,1.5$ and $2 \%$ vitamine C Kermanshahi and Riasi (2006) found that the total cholesterol amount decreased significantly $(P<0.05)$. In the present study (Table 7), it was found that blood plasma GGT values were numerically lower in all treatment groups. Low GGT value is evaluated as positive in terms of liver and animal health (Kale, 2019).

Table 8 shows the effects of vitamine $C$ and rosehip fruit added in roosters' ration on blood plasma values.

Table 7. The effect of addition of vitamine $C$ and Rosehip fruit doses to the ration on blood plasma values in laying hens.

\begin{tabular}{|c|c|c|c|c|c|c|c|}
\hline \multirow[b]{2}{*}{ Parameters } & \multicolumn{4}{|c|}{ Experiment Groups } & \multirow[b]{2}{*}{$\begin{array}{l}\text { Group } 5 \\
(15 \mathrm{~g} / \mathrm{kg}) \\
\text { Rosehip }\end{array}$} & \multirow[b]{2}{*}{ SEM } & \multirow[b]{2}{*}{$P$ value } \\
\hline & $\begin{array}{l}\text { Group } 1 \\
\text { (Control) }\end{array}$ & $\begin{array}{c}\text { Group } 2 \\
\text { (Commercial } \\
\text { ascorbic acid) }\end{array}$ & $\begin{array}{l}\text { Group } 3 \\
\text { (5g/kg) } \\
\text { Rosehip }\end{array}$ & $\begin{array}{l}\text { Group } 4 \\
(10 \mathrm{~g} / \mathrm{kg}) \\
\text { Rosehip }\end{array}$ & & & \\
\hline $\begin{array}{l}\text { Cholesterol } \\
(\mathrm{mg} / \mathrm{dL})\end{array}$ & 121.00 & 106.40 & 145.20 & 110.33 & 81.25 & 10.6112 & 0.3695 \\
\hline $\begin{array}{l}\text { Glucose } \\
\text { (mg/dL) }\end{array}$ & 223.00 & 232.00 & 212.20 & 235.50 & 239.75 & 3.6209 & 0.0942 \\
\hline $\begin{array}{l}\text { Triglyceride } \\
\text { (mg/dL) }\end{array}$ & $1214.00 \mathrm{a}$ & $980.33 a b$ & $409.60 c$ & $1163.83 a$ & $688.25 b c$ & 69.3159 & 0.0019 \\
\hline $\begin{array}{l}\text { Uric Acid } \\
\text { (mg/dL) }\end{array}$ & 4.08 & 3.78 & 4.80 & 4.82 & 5.55 & 0.3526 & 0.4711 \\
\hline $\begin{array}{l}\text { Sodium } \\
\text { (mmol/L) }\end{array}$ & 157.80 & 149.00 & 148.20 & 147.67 & 151.00 & 4.5826 & 0.4434 \\
\hline
\end{tabular}


It was found that the vitamine $C$ and rosehip fruit added in roosters' ration caused numerical differences in the amount of cholesterol, glucose, triglyceride, sodium, ALT, AST and GGT in roosters' blood plasma; however, this difference was not found to be statistically significant $(P>0.05)$. In terms of the amount of uric acid in blood plasma, the difference between the control group and the other groups was found to be statistically significant $(P<0.05)$. As can be seen in Table 7 and Table 8 , while the rosehip supplement caused a difference only in triglyceride levels of laying hens, it caused statistical difference only in uric acid in roosters $(P<0.05)$.

In roosters, uric acid level which was $11.03 \mathrm{mg} / \mathrm{dL}$ in the control group decreased in groups in which rosehip was added and it was found as 7.66, 8.30, 8.50 and $8.16 \mathrm{mg} / \mathrm{dL}$, respectively. Donsbough et al. (2010) reported that serum uric acid level could be used as an indicator of amino acid availability in broilers fed with sufficient and insufficient rations in terms of amino acid level. High uric acid level in plasma is considered as a risk factor for gout, renal diseases, metabolic syndrome and cardiovascular diseases (Oliveira and Burini, 2012).

\section{Conclusion}

When compared with high doses, low doses of rosehip fruit had a positive effect on hatching live weight; increased plasma vitamine $C$ content when compared with the control group and the group which was given commercial ascorbic acid supplement; reduced the level of triglyceride and reduced the level of uric acid in roosters. Due to these results, it can be recommended to add $5 \mathrm{~g} / \mathrm{kg}$ rosehip fruit instead of commercial ascorbic acid in the rations of laying hens and roosters exposed to high altitude and cold stress in order to meet their vitamine $C$ need. Using rosehip fruit as a feed additive in livestock will be a great benefit to our country's economy in terms of utilizing our natural resources. New comprehensive studies including sperm and all incubation parameters are needed to fully reveal the effect of rosehip fruit on breeding animals exposed to cold stress.

\section{Conflict of Interest}

The authors declare no conflict of interest.

\section{Acknowledgements}

This study was supported by the Scienctific Research Projects Coordination Unit of Van Yuzuncu Yil University as an individual research project numbered 2015-ZFB166.

\section{References}

Adesola, A. A., Ng'ambi, J. W., \& Norris, D. (2013). Effect of ascorbic acid supplementatıon to the diets of ındigenous venda hens on productivity of their progenıes aged 8 to
13 weeks. Agrıcultural Research Communıcatıon Centre, www.arccjournals.com/ indianjournals.com, Indian J. Anim. Res., 47 (2), 97-10.

Ağaoğlu, Y. S., Ayfer, M., Fidan, Y., Köksal, I.., Çelik, M., Abak, K., Çelik, H., Kaynak, L., Gülşen, Y. (1987). Bahçe Bitkileri, A.Ü.Z.F. Yay. 18-21, Ankara.

Ahmadu, S., Mohammed, A. A., Buharı, H., \& Auwal, A. (2016). An overview of vitamine $C$ as an antistress in poultry. Malaysian Journal of Veterinary Research, 7(2), 9-22.

Ahmed, W., Ahmad, S., Haq, A., \& Kamran, Z. (2008). Response of laying hens to vitamine $C$ suplementation through drinking water under sub-tropical conditions. Avtan Biolocy Research. 1(2), 59-63.

Akyıldız, A.R., 1984. Yemler Bilgisi Laboratuvar Klavuzu. A. Üniv. Zir. Fak. Yay:895, Uygulama Klavuzu:213. Ankara.

Altıner, A., Atalay, H., \& Bilal, T. (2017). Bir antioksidan olarak E vitaminei. Balikesir Sağlık Bil. Derg. Cilt:6 Sayı:3 Aralık149.

Anonim. (2008). Kuşburnu Yetiştiriciliği. http://www.tarim.gov.tr/ ( 08.06.2015).

Anonymous. (2013). European Union Register of Feed Additives Pursuantto Regulation. (EC) No 1831/2003. Appendixes 3c\&4. Annex: List of Additives, Edition 163, 458p.http://ec.europa.eu/food/food/animalnutrition/f eedadditives/comm_register_feed_additives_183103.pdf.

AOAC, 1984. Official Methods of Analysis (14th ed.). Association of Official Analitical Chemists, Washington, DC.

Arpat, Ş. (2016). Yumurta tavuğu rasyonlarına kuşburnu ilavesinin performans, yumurta iç ve dış kalite özelliklerine etkisi. Yüksek Lisans Tezi, Erciyes Üniversitesi Sağlık Bilimleri Enstitüsü, Kayseri.

Behboudi, H., Esmaeilipour, O., Mirmahmoudi, R., \& Mazhari, M. (2016). The influence of drinking water containing lemon juice and thyme suplemented diet on performance and some blood parametres of broilers under heat stress. Iranian Journal Applied Animal Science. ISSN:2251-620X(Print), ISSN:2251$631 X($ Online).

Bek, Y., Efe E. (1998). Araştırma ve Deneme Metodları 1. Ç.Ü Ziraat Fakültesi Ders Kitabı No:71, Adana.

Bown, D. (1996). Encyclopedia of Herbsand Their Uses. The Royal Horticultural Society, Dorling Kindersley Limited, 424 p. London.

Cemeroğlu, B. (2007). Gıda Analizleri. Gıda Teknolojisi Derneği Yayınları. Ankara, No: 34: 168-171.

Çınar, İ., Alma H., Çolakoğlu, A.S. (2004). Kuşburnu Karotenoid Pigmentlerinin Ekstraksiyonu ve Gıdalarda Kullanım Potansiyellerinin Belirlenmesi. ss:198-200., Gelenksel Gıdalar Sempozyumu Bildiriler Kitabı. Van.

Değirmencioğlu, T., \& Ak, A. (2003). Güz döneminde besiye alınan hindilerde askorbik asit uygulamasının besi performansı ve bazı kasrkas özelliklerine etkileri. Ulud. Üniv. Ziraat Fak. Derg. 17 (2):18.

Demir, F., \& Özcan, M. (2001). Chemical and technological properties of rosa (Rosa canina L.) Fruits Grown Wild in Turkey. Journal of Food Engineering. 47 333-336.

Donsbough, A.L., Powell, S., Waguespack, A., Bidner, T.D., \& Southern, L.L. (2010). Uric acid, urea, and amonia concentrations in serum and uric acid concentration in excreta as indicators of amino acid utilization in diets for broilers. Poultry Science, February. 287-294.

Kadakal, Ç., \& Nas, S. (2004). Kuşburnu deyip geçmeyin. Cine Tarım Dergisi Sayı 49. 
Kale, O. (2019). Koyunlarda yeme zeolit ve yucca schidigera ilavesinin bazı karaciğer enzimlerine (AST, ALT, GGT) etkilerinin karşılaştırılmas. T.C. Afyon Kocatepe Üniversitesi, Sağlık Bilimleri Enstitüsü Veteriner Biyokimya Anabilimdalı. Yüksek Lisans Tezi, Afyonkarahisar.

Kamanlı, S., Durmuş, İ. (2014). Civciv kalitesi değerlendirme yöntemleri ve civciv kalitesinin iyileştirilmesi konusundaki son yaklaşımlar. Tavukçuluk Araştırma Dergisi, 11(1): 40-44.

Karatepe, M. (2004). Simultaneous Determination of Ascorbic Acid and Free Malondialdehyde in Human Serum by HPLC-UV. LCGC North America, 22, 362-365.

Kermanshahi, H., \& Raisi, A. (2006). Effect of diatery dried berberis vulgaris fruit and enzyme on some blood parameters of laying hens fed wheat-soybean diets. International Journal of Poultry Science 5 (1): 89-92.

Kutlu, H.R. (2009). Kanatı Hayvan Besleme. Tavukçuluk Bilimi: Yetiştirme, Besleme, Hastalıklar. Editörler: Prof. Dr. Mesut Türkoğlu, Prof. Dr. Musa Sarıca. Bey Ofset Matbaacilık, Ankara

Kutlu, H.R., \& Forbes, J.M. (1993). Changes in growthand blood parameters in heat-stressed broiler chickes in responseto dietary ascorbik acid. Livestock Prod. Sci. 36, 335-350.

Miller, K.W., \&Yang, C.S. (1985). An isocratic high-performance liquid chromatography method for the simultaneous analysis of plasma retinol, alpha-tocopherol and various carotenoids. Anal. Biochem. 145: 21-26.

Mutlu, S.i., Çelik, Ö., Bayrak, O., Emreoğlu, L., Terlemez, F., Azman, M.A., Şimşek, Ü.G., Özçelik, M., Çerçi, i.H., Kenar, M., \& Çiftçi, M. (2015). Soğuk stres koşulları altında bıldırcın karma yemlerine ilave edilen saponin bakımından zenginleştirilmiş çöven ekstraktının performans ve kan parametreleri üzerine etkileri. F.Ü. Sağ. Vet. Derg. 29(2) 103-109.

Oliveira, E.P., \& Burini R.C. (2012). High plasma uric acid concentration: causes and consequences. Diabetology \& Metabolic Syndrome, 4:12http://www.dmsjournal.com/content/4/1/12.

Saraçoğlu, i.A. (2006). Bitkisel Sağlık Rehberi. 40. Baskı, s:202. Gün Ofset, ISBN: 975-92837. 1-9, İstanbul.

SAS. (2010). Applied statistics and the SAS programming language. Third Editions.
Sasidhar, P.V.K. (2020). Poultry Research Priorities to 2020 Proceedings of National Seminar. Central Avian Research Institute (Indian Council of Agricultural Research) Izatnagar. 243122 (U.P.) India.

Shakeri, M., Oskoueian, E., Le, H.H., \& Shakeri. M. (2020). Strategies to combat heat stress in broiler chickens: unveiling the roles of selenium, vitamine $\mathrm{E}$ and vitamine C. (Review). Vet. Sci.2020, 7,71;doi:10.3390/vetsci 7020071.

Shit, R.P., Singh, K., Sastry, R., Agarwal, R., Singh, N., \& Pandey, (2012). Effect of dietary I-ascorbic acid (I-aa) on production performance, egg quality traits and fertility in japanese quail (coturnix japonica) at low ambient temperature. Asian-Aust. J. Anim. Sci. Vol. (2012): 25, No. 7: 1009-1014.

Şeremet, Ç. (2012). Civciv kalitesini etkileyen etmenler ve değerlendirme yöntemleri. Hayvansal Üretim 53(1): 3843.

Tada, H., Nohara, A., \& Kawashiri, M. (2018). Serum triglycerides and atherosclerotic cardiovascular disease: Insights from clinical and genetic studies. Nutrients. 10, 1789; doi:10.3390/nu10111789, 2-8.

Tekeli, A. (2014). Effect of rosehip fruit (Rosa canina L.) Supplementation to rations of broilers grown under cold stress conditions on some performance, blood, morphological, carcass and meat quality characteristics. European Poultry Science. 78.

Türkben, C. (2003). Kuşburnu. Uludağ Üniversitesi Basımevi. ISBN:975-6958,70-7.

Türker, i., İbas, T., \& Ertürk, Ö. (2018). Kuluçkalık yumurtaların değişik oranlarda propolis ile dezenfekte edilmesinin kuluçka sonuçları ve toplam bakteri sayısı üzerine etkisi. Akademik Ziraat Dergisi. 7(1):67-74.

Untea, A.E., Varzaru, I., Panaite, T.D., Gavris, T., Lupu, A., \& Ropota, M. (2020). The effects of dietary inclusion of bilberry and walnut leaves in laying hens diets on the antioxidant properties of eggs. Animals.10,191; doi:103390/ani10020191.

Zaspel, B.J., \& Csallany, A.S. (1983). Determination of alphatocopherol in tissues and plasma by high-performance liquid chromatography. Anal Biochem.,130: 146-150. 